\title{
The relationship between B-type natriuretic peptide levels and echocardiographic parameters in patients with heart failure admitted to the emergency department
}

\author{
Acil servise başvuran kalp yetersizliği hastalarında BNP düzeyleri ve \\ ekokardiyografik parametrelerin ilişkisi
}

\author{
Evvah Karakılıç, Alper Kepez1, Gülcan Abalı², Figen Coşkun³, Mahir Kunt, Lale Tokgözoğlu* \\ From Departments of Emergency Medicine and *Cardiology, Faculty of Medicine, Hacettepe University, Ankara \\ ${ }^{1}$ Clinic of Cardiology, Eskişehir Yunus Emre State Hospital, Eskişehir \\ ${ }^{2}$ Clinic of Cardiology, Acıbadem Hospital, Adana \\ 3Department of Emergency Medicine, Ankara Education and Research Hospital, Ankara, Turkey
}

ABSTRACT

Objective: Brain natriuretic peptide (BNP) is a peptide, which has recently been used in the differential diagnosis and follow-up of patients with heart failure. Our aim in the present prospective and diagnostic designed study is to investigate the role of BNP in determining the etiology of dyspnea and to evaluate its relation with newer echocardiographic parameters.

Methods: Thirty-four patients presenting to the emergency department with dyspnea and fulfilling the Framingham criteria for heart failure were included in the study. Blood samples were obtained in the first hour of presentation for measurement of BNP levels from all patients. Detailed transthoracic two-dimensional, Doppler and tissue Doppler echocardiographic studies were then performed within 24 hours of presentation. Statistical analyses were performed using Student's t-test for independent samples, Mann Whitney U test and Pearson or Spearman correlation tests.

Results: Plasma BNP levels were found to be significantly correlated with left ventricular end-systolic and end-diastolic diameter, left atrial diameter and the degree of mitral insufficiency $(r=0.46, p=0.007 ; r=0.39, p=0.02 ; r=0.32, p=0.065 ; r=0.50, p=0.014$, respectively). A significant inverse correlation was observed between plasma BNP levels and left ventricular ejection fraction ( $r=-0.5, p=0.003)$. When the patients were grouped according to their BNP levels, the mean ejection fraction of the group with BNP levels below median (578 pg/l) was $60.65 \pm 13.84 \%$, whereas the mean ejection fraction of the group with BNP levels of $578 \mathrm{pg} / \mathrm{l}$ or above (BNP 2) was $49.41 \pm 15.26 \%$ ( $p=0.027$ ). Out of parameters reflecting left ventricular diastolic functions, only transmitral Epeak/Apeak ratio was found to be significantly associated with $B N P$ levels $(r=0.4, p=0.05)$. Tissue Doppler study revealed significant correlations between BNP levels and right ventricular basal and midsystolic velocities $(r=-0.507, p=0.008$; $r=-0.562, p=0.005$, respectively) while none of the left ventricular tissue velocities displayed significant correlation with BNP values.

Conclusion: Plasma BNP levels are found to be significantly associated with conventional echocardiographic parameters reflecting left ventricular systolic and diastolic functions and tissue Doppler velocities reflecting right ventricular functions. Our findings are in agreement with the notion that plasma BNP levels are beneficial in the differential diagnosis of patients admitted to emergency service with acute dyspnea. (Anadolu Kardiyol Derg 2010; 10: 143-9)

Key words: Natriuretic peptide, heart failure, echocardiography, color Doppler echocardiography, tissue Doppler echocardiography, stroke volume, diagnostic value of tests

ÖZET

Amaç: Beyin natriüretik peptit (BNP) kalp yetersizliği olan hastaların ayıııcı tanısında ve takibinde kullanılan bir peptitdir. Prospektif ve diyagnostik dizaynı olan bu çalışmada amacımız, BNP'nin nefes darlığının etiyolojisini belirlemedeki rolü ve yeni ekokardiyografik parametrelerle ilişkisini araştırmaktır. Yöntemler: Acil servise nefes darlığı ile başvuran ve kalp yetersizliği yönünden “Framingham” kriterlerine uygun 34 hasta çalışmaya alındı. Tüm hastalardan başvurdukları ilk saat içerisinde BNP düzeyi ölçümü için kan örnekleri alındı ve tüm hastalara başvurudan sonraki 24 saat içinde ayrıntılı transtorasik iki-boyutlu, Doppler ve doku Doppler ekokardiyografi çalışmaları yapıldı. İstatistiksel analizde bağımsız örneklem Student's t-testi, Mann Whitney U testi ve Pearson veya Spearman testleri kullanıldı.

Address for Correspondence/Yazışma Adresi: Dr. Evvah Karakılıç, Hacettepe University Faculty of Medicine, Department of Emergency Medicine, Ankara, Turkey Phone: +903123052506 Fax: +90312305 2514 E-mail: evvah@gmail.com

This work was partly presented at the $3^{\text {rd }}$ Mediterranean Emergency Medicine Congress, 1-5 September, 2005, Nice, France

Accepted/Kabul Tarihi: 03.12.2009

(C) Telif Hakkı 2010 AVES Yayıncılık Ltd. Sti. - Makale metnine www.anakarder.com web sayfasından ulaşılabilir.

(C) Copyright 2010 by AVES YayıncIllk Ltd. - Available on-line at www.anakarder.com doi:10.5152/akd.2010.040 
Bulgular: Plazma BNP düzeyleri ile sol ventrikül sistol sonu çapı, diyastol sonu çapı, sol atriyal çap ve mitral yetmezlik derecesi arasında, pozitif yönde istatistiksel olarak anlamlı korelasyon olduğu görüldü (sırası ile $r=0.46, p=0.007 ; r=0.39, p=0.02 ; r=0.32, p=0.065 ; r=0.50, p=0.014$ ). Plazma BNP düzeyleri ile sol ventrikül ejeksiyon fraksiyonu arasında negatif yönde anlamlı korelasyon tespit edildi $(r=-0.5, p=0.003)$. Beyin natriüretik peptit medyan değerine göre, hastalar eşit iki gruba bölündüğünde BNP düzeyleri medyan değeri altında olan hastaların ejeksiyon fraksiyonu değerlerinin, BNP düzeyleri medyan değere eşit veya daha fazla olan gruba göre anlamlı derecede yüksek olduğu izlendi $(\% 60.65 \pm 13.84$ ve $\% 49.41 \pm 15.26, p=0.027)$. Sol ventrikül diyastolik fonksiyonları yansıtan parametrelerden yalnız transmitral Epeak/Apeak değerinin BNP düzeyleri ile anlamlı olarak ilişkili olduğu saptandı $(r=0.4, p=0.05)$. Doku Doppler çalışmasında, sol ventrikülden alınan doku Doppler velositeleri ile BNP düzeyleri arasında anlamlı korelasyon saptanmaz iken, sağ ventrikül bazal ve orta peak sistolik hızları ile BNP düzeyi arasında negatif yönde anlamlı korelasyon olduğu saptandı (sırası ile $r=-0.507, p=0.008 ; r=-0.562, p=0.005$ ).

Sonuç: Plazma BNP düzeyleri, sol ventrikül sistolik ve diyastolik fonksiyonları yansıtan konvansiyonel parametreler ile sağ ventrikül fonksiyonIarını yansıtan doku Doppler velositeleri ile anlamlı düzeyde ilişkili bulundu. Bu bulgular acil serviste BNP düzeyleri çalışmasının nefes darlığı ile başvuran hastalarda ayıııc tanıya yardımcı olabileceğini desteklemektedir. (Anadolu Kardiyol Derg 2010; 10: 143-9)

Anahtar kelimeler: Natriüretik peptid, kalp yetersizliği, ekokardiyografi, renkli Doppler ekokardiyografi, doku Doppler ekokardiyografi, atım hacmi, testlerin diyagnostik değerleri

\section{Introduction}

Brain natriuretic peptide (BNP) is a polypeptide, which has recently been used in the differential diagnosis and follow-up of patients with congestive heart failure. It is a neurohormone released by the ventricular myocytes and plays a key role in volume homeostasis (1-2). Plasma BNP level is a sensitive indicator of ventricular dysfunction both in symptomatic and asymptomatic patients and its plasma concentration increases with volume and pressure overload in patients with heart failure (3-5). In addition to, the left ventricular (LV) systolic dysfunction, plasma BNP levels have been suggested to be significantly associated with diastolic stage (including newer echocardiographic parameters as tissue Doppler imaging and color M-mode propagation velocity) and right ventricular (RV) functions as well (6-9). Though the relationship between BNP and left and right ventricular functions have been elucidated in patients with systolic heart failure (10), the diagnostic value of BNP in prediction of right and left ventricular systolic/diastolic functions in patients with acute heart failure is not well established and literature data are controversial (11).

The Framingham clinical criteria can be used for the clinical diagnosis of heart failure. Accordingly, the major criteria are paroxysmal nocturnal dyspnea, orthopnea, elevated jugular venous pressure, pulmonary rales, third heart sound, cardiomegaly on chest X-ray, pulmonary edema on chest X-ray, weight loss $\geq 4.5 \mathrm{~kg}$ in five days, in response to treatment of presumed heart failure. The minor criteria are bilateral leg edema, nocturnal cough, dyspnea on ordinary exertion, hepatomegaly, pleural effusion, tachycardia (heart rate $\geq 120$ beats/min), and weight loss $\geq 4.5 \mathrm{~kg}$ in five days. The diagnosis of heart failure requires the presence of 2 major or 1 major and 2 minor criteria that cannot be attributed to another medical condition (12).

Echocardiography is the method of choice in the evaluation of heart failure and in detection of LV systolic and diastolic functions because of its feasibility and noninvasive nature. Since conventional transmitral Doppler parameters reflecting LV diastolic function [transmitral peak early diastolic filling velocity (E), transmitral peak late diastolic filling velocity $(A)$, isovolumic relaxation time (IVRT) and E wave deceleration time (Edec)] are rather dependent on loading conditions, new echocardiographic techniques that are affected to a lower extent from preload and afterload were emerged in the recent years for evaluation of LV diastolic function [pulsed-wave Doppler tissue velocities, mitralcolor propagation velocity (mCP)]. Subclinical myocardial damage may be detected by the tissue Doppler method, even when the conventional echocardiographic parameters are normal (13). Pulsed-wave tissue Doppler velocities (both systolic and diastolic), strain (the total percentage of deformation of myocardial segment, the percentage of shape distortion) and strain rate (the rate of deformation in the unit time) parameters can be measured by using tissue Doppler analysis and these parameters can be used to document subtle myocardial dysfunction.

The aim of the present study is to investigate the relation of plasma BNP levels with various echocardiographic parameters and to evaluate the role of BNP for detecting left and right ventricular dysfunction in patients admitted to the emergency service with acute heart failure symptoms.

\section{Methods}

This is a prospective, diagnostic test evaluation study. The study confirms to the principles outlined in the Declaration of Helsinki and the study protocol was approved by Hacettepe University Ethics Committee; written informed consent was obtained from all participants. There was no involvement of the manufacturer of the Triage BNP (Biosite Diagnostics, Inc. San Diego, CA) test on collection, analysis and interpretation of the data.

\section{Selection and description of participants}

Thirty-four consecutive patients who admitted to the emergency service with acute heart failure symptoms were included in the study. Medical histories, clinical findings, blood test results, electrocardiographic findings and chest radiography results were evaluated by emergency physicians. Patients with a known history of primary pulmonary disease including asthma, chronic obstructive pulmonary disease (COPD), bronchial hyper-reactivity, pneumonia and dyspnea related to trauma or laryngeal pathology were excluded from study. Other exclusion criteria were acute myocardial infarction, unstable angina (evaluated by electrocardiogram and cardiac enzymes) and atrial fibrillation. 


\section{BNP test}

Plasma BNP levels were measured on admission using a quantitative fluorescence immunoassay (Triage-BNP Meter, Biosite Diagnostics, Ins. San Diego, California). After separating from the red blood cells, plasma was moved by capillary action into a reaction chamber and was made to react with murine monoclonal anti-BNP antibodies, which were labeled with fluorescence. After incubation period, the reaction mixtures were moved to the detection lane of device and were captured with polyclonal anti-BNP antibodies that were immobilized on solid phase and unbound fluorescent antibody was washed. The concentration of BNP is proportional to the fluorescence bound to the detection lane. The measurement range is $5-5000 \mathrm{pg} / \mathrm{ml}$. The average $95 \%$ confidence limit of the analytical sensitivity of the Triage BNP test is less than $5 \mathrm{pg} / \mathrm{ml}$ (95\% Cl: 0.2 to $4.8 \mathrm{pg} / \mathrm{L})$.

\section{Echocardiographic measurements}

All echocardiographic examinations were performed by the same operator using commercially available equipment (Vivid Five, GE Vingmed, Norway). Standard echocardiographic examination was performed using a $2.5-\mathrm{MHz}$ probe. Systolic and diastolic LV dimensions, ejection fraction (EF) and fractional shortening values were measured in the parasternal view. Mitral inflow measurements were obtained from the apical 4-chamber view placing the sample volume at the leaflet tips of the open mitral valve. Isovolumic relaxation time was measured from the continuous-wave Doppler signal of the simultaneous aortic and mitral valve flows from the apical 5 -chamber view with the sample volume placed between the LV outflow tract and mitral valve.

Doppler tissue myocardial velocities were measured in the apical 4-chamber view sampling the septal mitral annulus, lateral mitral annulus, RV lateral wall at the tricuspid annulus level and mid-septal, mid-lateral and mid-right ventricular segments. To minimize the angle between the beam and the direction of annular motion, care was taken to keep the ultrasound beam perpendicular to the plane of the annulus. Peak systolic myocardial wave $S^{\prime}$ and early and late diastolic peak myocardial velocities ( $E^{\prime}$ and $\left.A^{\prime}\right)$ were recorded. Several cardiac cycles were evaluated and the best 3 consecutive ones were analyzed and averaged.

Strain (S) and strain rate (SR) analyses were performed using the color tissue Doppler images obtained from apical 4-chamber, apical 2-chamber and apical long-axis views. Twodimensional color Doppler myocardial imaging data were recorded at a frame rate of $64 \pm 6$ frames/s on the Echopac system for off-line analysis (Vivid Five, GE, Vingmed, Norway). Regional strain and SR data were then automatically obtained from the following regions of interest: LV basal septal, mid-septal, basal lateral, mid-lateral and RV basal and mid segments (Fig. 1). Average strain and SR of the 4 LV and 2 RV segments were calculated as an estimate of global LV and RV long-axis function.

\section{Statistical analysis}

Statistical Package for Social Sciences (SPSS for Windows, Chicago, IL, USA) version of 11.0 was used for data analysis. Distribution of data was assessed by using one-sample Kolmogorov-Smirnov test. Values displaying normal distribution were expressed as the mean $\pm S D$ and values not displaying normal distribution were expressed as median (interquartile range). Differences between numeric variables were tested with independent samples Student's $t$-test or Mann Whitney U test where appropriate. Correlation between plasma BNP levels and other parameters was tested by Pearson or Spearman correlation tests where appropriate. The value of statistical significance was accepted as: " $p<0.05$ ".

\section{Results}

Thirty-four subjects were included in the study (16 male, 18 female). Mean age of study population was $74.1 \pm 10.7$ years. Among study population, 29 patients (85.3\%) were observed to have class IV and 5 patients (14.7\%) were observed to have class III heart failure according to the classification by the New York
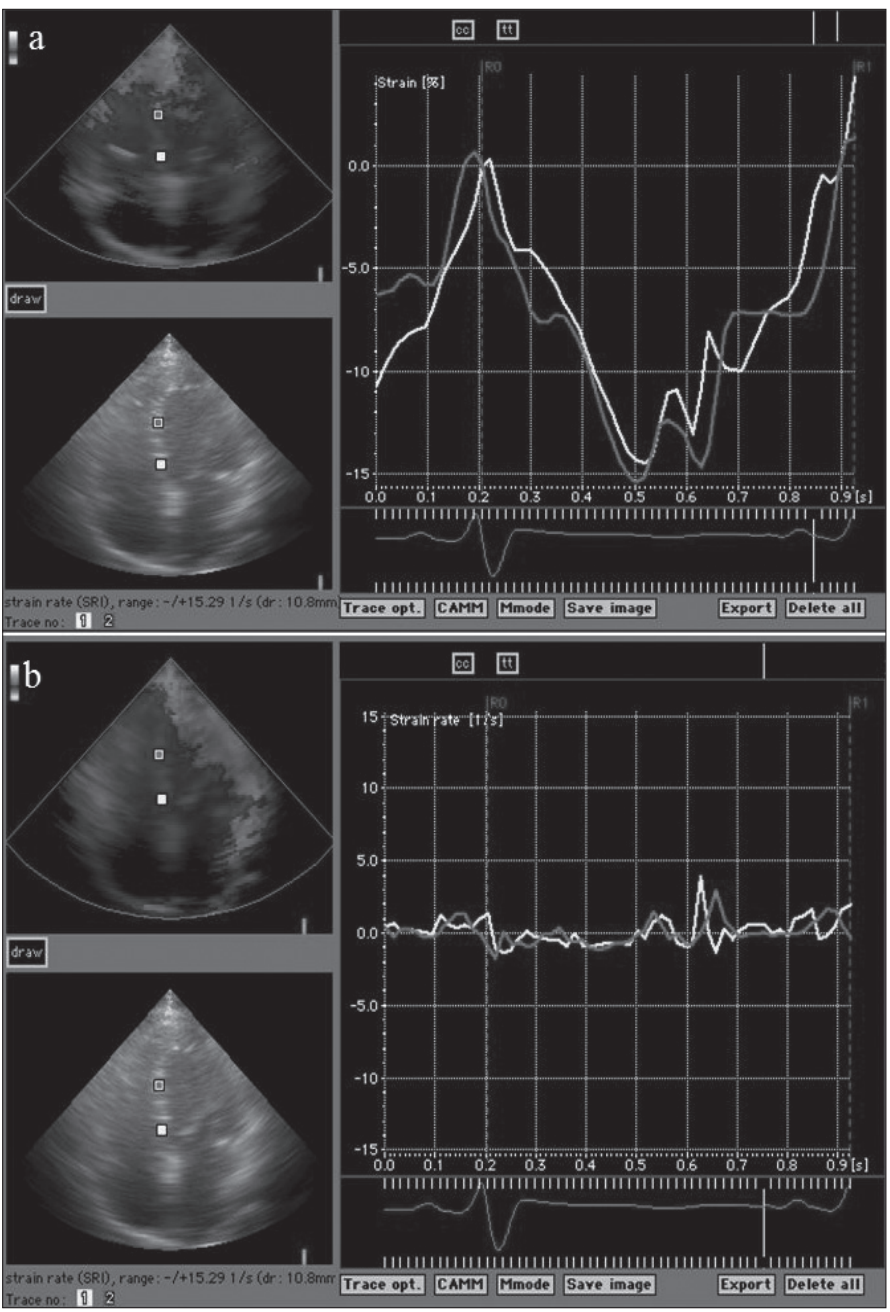

Figure 1. Schematic representation of strain (a) and strain rate (b) analysis of septal segments 
Heart Association. Demographic and clinical characteristics of the patients are presented on Table 1. The echocardiographic measurements of the 34 patients including parameters of M-mode, transmitral Doppler, tissue Doppler and strain analysis and serum BNP levels are presented in Table 2. The distribution of the BNP levels is presented in Figure 2.

The mean EF was $55.0 \%$. Out of study population, $15(44.1 \%)$ patients were observed to have systolic dysfunction $(E F<55 \%)$ and $19(55.9 \%)$ patients were observed to have diastolic dysfunction ( $E F \geq 55 \%$ ), respectively. We detected a negative correlation between ejection fraction and BNP levels $(p<0.01)$. When the patients were grouped according to their BNP levels, the mean ejection fraction of the group with BNP levels below median $(578 \mathrm{pg} / \mathrm{l})$ was $60.65 \pm 13.84 \%$, whereas the mean ejection fraction of the group with BNP levels of $578 \mathrm{pg} / \mathrm{l}$ or above (BNP 2) was $49.41 \pm 15.26 \%(p=0.027)$. Mitral regurgitation was classified 1 to 4 and the median value was 2 . There was a positive correlation between mitral regurgitation and BNP levels $(p=0.014$, $\mathrm{n}=31$ ). There were no statistically significant correlations between BNP levels and E, A peak velocities, IVRT and Edec values. However a statistically significant relation was detected between BNP levels and E/A ratio, which has been suggested to provide a better reflection of LV function ( $p=0.05$ ) (14). On pulsed- wave tissue Doppler recordings, right ventricular basal peak systolic flow and right ventricular middle peak systolic wave displayed a statistically significant association with BNP levels (Table 3). Among peak longitudinal systolic strain and strain rate values, only the negative correlation between BNP levels and mid-septal peak systolic strain values was statistically significant $(p<0.05)$. Serum BNP levels and echocardiographic parameters which were significantly related to serum BNP levels are presented in Table 3.
There were significant differences regarding LV ejection fraction, left atrial diameter, E/A ratio, right ventricular basal peak systolic velocity and LV mid-septal peak systolic strain values between BNP groups and all are depicted on Table 4.

\section{Discussion}

Chronic heart failure has an increasing frequency among the elderly in developed countries. The clinical diagnosis of chronic heart failure, only by means of symptoms, is difficult and the symptoms such as dyspnea are usually not specific $(15,16)$.

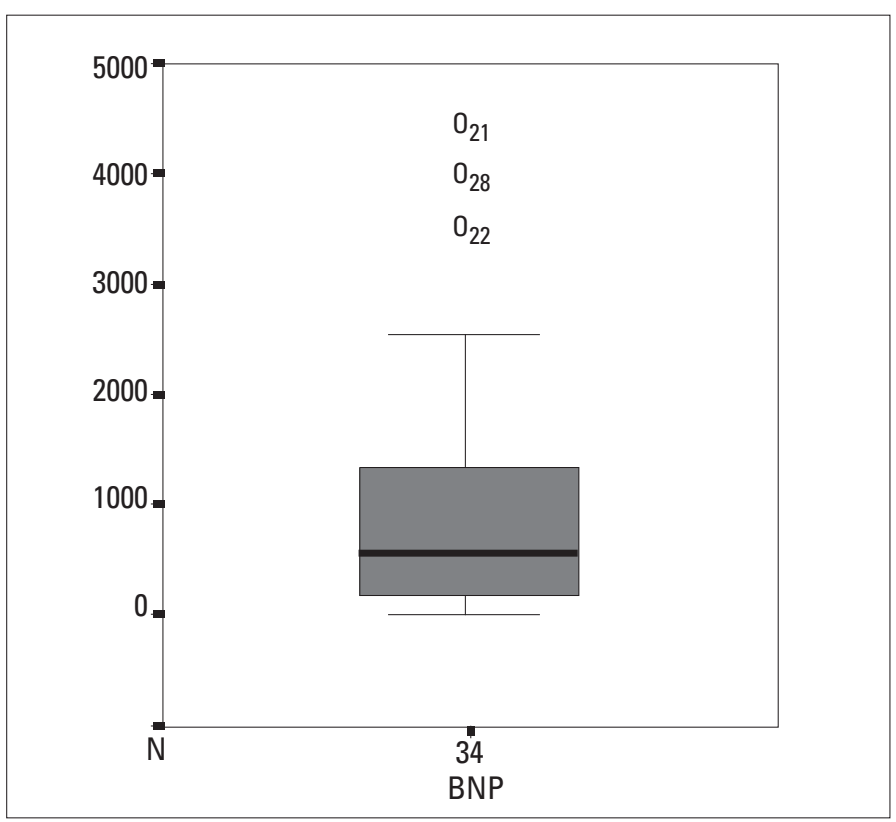

Figure 2. The distribution of the B-type natriuretic peptide (BNP) level

Table 1. Demographic and clinical characteristics of the patients

\begin{tabular}{|c|c|c|c|c|}
\hline Variables & All Patients & BNP 1 & BNP 2 & *p \\
\hline Number of patients & 34 & 17 & 17 & NS \\
\hline Gender Male/Female, n & $16 / 18$ & $10 / 7$ & $8 / 9$ & NS \\
\hline Age, years & $74.1 \pm 10.7$ & $71.9 \pm 12.5$ & $76.3 \pm 8.3$ & NS \\
\hline $\mathrm{EF}, \%$ & $55.03 \pm 15.44$ & $60.65 \pm 13.84$ & $49.41 \pm 15.26$ & 0.027 \\
\hline Hypertension, n (\%) & $23(67.6)$ & $10(58.8)$ & $13(76.5)$ & NS \\
\hline History of coronary artery disease, $\mathrm{n}(\%)$ & $20(58.8)$ & $9(52.9)$ & $11(64.7)$ & NS \\
\hline \multicolumn{5}{|c|}{ Clinical classification according to NYHA, $n(\%)$} \\
\hline Class III & $5(14.7)$ & $3(17.6)$ & $2(11.8)$ & \multirow[t]{2}{*}{ NS } \\
\hline Class IV & $29(85.3)$ & $14(82.4)$ & $15(88.2)$ & \\
\hline \multicolumn{5}{|l|}{ Echocardiographic classification, n (\%) } \\
\hline Systolic dysfunction & $15(44.1)$ & $5(29.4)$ & $10(58.8)$ & \multirow[t]{2}{*}{ NS } \\
\hline Diastolic dysfunction & $19(55.9)$ & $12(70.6)$ & $7(41.2)$ & \\
\hline $\begin{array}{l}\text { Data are represented as mean } \pm S D \text { and proportions/perc } \\
\text { *Student's t and Chi-square tests } \\
\text { BNP1- patients group whose BNP levels were below } 578 \\
\text { BNP2- patients group whose BNP levels were } 578 \mathrm{pg} / \mathrm{l} \text { a } \\
\text { BNP - brain natriuretic peptide, EF - ejection fraction, NY }\end{array}$ & k Heart Association & & & \\
\hline
\end{tabular}


Table 2. Echocardiographic measurements of study population

\begin{tabular}{|c|c|c|c|c|c|c|}
\hline Variables & $\mathbf{N}$ & Minimum & Maximum & Mean & Median & Standard deviation \\
\hline Age, years & 34 & 51 & 97 & 74.15 & 76.00 & 10.7 \\
\hline BNP, pg/l & 34 & 16 & 4410 & 996.5 & 578.00 & 1165.5 \\
\hline LVEDD, cm & 34 & 3.1 & 8.8 & 5.49 & 5.60 & 1.21 \\
\hline LVESD, cm & 34 & 2 & 7.2 & 3.97 & 3.80 & 1.26 \\
\hline$E F, \%$ & 34 & 24 & 86 & 55.03 & 56.00 & 15.44 \\
\hline $\mathrm{LA}, \mathrm{cm}$ & 34 & 2.4 & 6.5 & 4.53 & 4.40 & 0.93 \\
\hline $\mathrm{E}, \mathrm{m} / \mathrm{sec}$ & 32 & 0.42 & 1.8 & 0.93 & 0.90 & 0.31 \\
\hline $\mathrm{A}, \mathrm{m} / \mathrm{sec}$ & 32 & 0.34 & 1.64 & 0.92 & 0.91 & 0.35 \\
\hline IVRT, ms & 31 & 38 & 128 & 86.97 & 88.20 & 23.5 \\
\hline EDec, ms & 32 & 1.39 & 370 & 180.65 & 160.00 & 92.78 \\
\hline $\mathrm{MR}^{*}$ & 31 & 1 & 4 & 2.04 & 2.00 & 0.77 \\
\hline RVBS, cm/sec & 32 & 7.09 & 25 & 14.38 & 14.33 & 3.6 \\
\hline RVMS, cm/sec & 32 & 7.6 & 15.65 & 11.60 & 11.30 & 2.11 \\
\hline SSM, \% & 32 & 1.17 & 33.28 & 13.69 & 12.57 & 8.18 \\
\hline Mean strain rate ${ }^{* *}, 1 / \mathrm{sec}$ & 32 & 0.8 & 3.91 & 1.97 & 1.78 & 0.67 \\
\hline Mean strain**, \% & 32 & 5.35 & 26.02 & 16.44 & 17.48 & 4.58 \\
\hline \multicolumn{7}{|c|}{$\begin{array}{l}\text { Descriptive statistics of variables are presented } \\
\text { A-peak transmitral late flow velocity, EDec-mitral E deceleration time, EF-ejection fraction, E-peak transmitral early flow velocity, IVRT-isovolumetric relaxation time, LA-left atrium, LVEDD-left } \\
\text { ventricular end-diastolic diameter, LVESD-left ventricular end- systolic diameter, MR-mitral regurgitation, N-number of patients, RVBS-right ventricle basal peak systolic flow, RVMS-right ventricle } \\
\text { mid peak systolic flow, SSM-strain mid-septal } \\
\text { * Mitral regurgitation classified grade } 1 \text { to } 4 \\
\text { ** Strain and strain rate mean values }\end{array}$} \\
\hline
\end{tabular}

Table 3. Significant correlations between BNP levels and echocardiographic measurements

\begin{tabular}{|c|c|c|c|}
\hline \multirow[t]{2}{*}{ Variables } & \multicolumn{2}{|c|}{ Plasma BNP, pg/l } & \multirow[t]{2}{*}{$\mathbf{N}$} \\
\hline & $r$ & p & \\
\hline LVESD, cm & 0.46 & $0.007^{*}$ & 34 \\
\hline LVEDD, cm & 0.39 & $0.022^{*}$ & 34 \\
\hline $\mathrm{EF}, \%$ & -0.5 & $0.003^{*}$ & 34 \\
\hline $\mathrm{LA}, \mathrm{cm}$ & 0.32 & 0.065 & 34 \\
\hline E/A ratio & 0.4 & $0.05^{*}$ & 32 \\
\hline MR & 0.50 & $0.014^{*}$ & 31 \\
\hline RVBS, cm/sec & -0.507 & $0.008^{*}$ & 32 \\
\hline RVMS, cm/sec & -0.562 & $0.005^{*}$ & 32 \\
\hline SSM, 1/sec & -0.453 & $0.026^{*}$ & 32 \\
\hline \multicolumn{4}{|c|}{$\begin{array}{l}\text { Pearson correlation test } \\
\text { BNP - brain natriuretic peptide, EF - ejection fraction, E/A - /A-ratio of peak early to late dia- } \\
\text { stolic filling velocity, LA - left atrium, LVEDD - left ventricular end-diastolic diameter } \\
\text { LVESD - left ventricular end-systolic diameter, MR - mitral regurgitation, RVBS - right ventricle } \\
\text { basal peak systolic flow, N - number of patients, RVMS - right ventricular mid peak systolic } \\
\text { flow, SSM - strain mid-septal } \\
\text { *Statistically significant }(p<0.05)\end{array}$} \\
\hline
\end{tabular}

Rapid diagnosis is very important in decompensated heart failure, because of the need for prompt treatment. Studies in recent years indicate the presence of some kind of neurohormonal activation in heart failure pathophysiology and some markers of
Table 4. Echocardiographic parameters of BNP 1 and BNP 2 groups

\begin{tabular}{|c|c|c|c|}
\hline Variables & BNP 1 & BNP 2 & ${ }^{*} p$ \\
\hline LVESD,cm & $3.58 \pm 1.16$ & $4.35 \pm 1.27$ & 0.081 \\
\hline LVDD, cm & $5.15 \pm 1.25$ & $5.81 \pm 1.09$ & 0.157 \\
\hline$E F, \%$ & $60.65 \pm 13.84$ & $49.41 \pm 15.26$ & $0.027^{*}$ \\
\hline $\mathrm{LA}, \mathrm{cm}$ & $4.18 \pm 0.85$ & $4.82 \pm 0.92$ & $0.044^{*}$ \\
\hline E/A ratio & $0.99 \pm 0.61$ & $1.56 \pm 1.11$ & $0.042^{*}$ \\
\hline $\mathrm{MR}^{* *}$ & $2.00(1.00)$ & $2.00(1.00)$ & 0.088 \\
\hline RVBS, cm/sec & $15.27 \pm 1.98$ & $13.15 \pm 4.90$ & $0.040^{*}$ \\
\hline RVMS, cm/sec & $12.28 \pm 1.82$ & $10.52 \pm 2.16$ & 0.059 \\
\hline SSM, \% & $16.59 \pm 7.26$ & $9.60 \pm 7.95$ & $0.022^{*}$ \\
\hline \multicolumn{4}{|c|}{$\begin{array}{l}\text { Data are represented as Mean } \pm \text { SD and **median (IOR) } \\
\text { *Students t test or Mann-Whitney U test } \\
\text { BNP1-patients group whose BNP levels were below } 578 \mathrm{pg} / \mathrm{l} \\
\text { BNP2-patients group whose BNP levels were } 578 \mathrm{pg} / \text { and above } \\
\text { BNP - brain natriuretic peptide, EF-ejection fraction, E/A-ratio of peak early to late diastolic } \\
\text { filling velocity, LA-left atrium, LVEDD-left ventricular end-diastolic diameter, LVESD-left } \\
\text { ventricular end-systolic diameter, MR-mitral regurgitation, RVBS-right ventricle basal peak } \\
\text { systolic velocity, RVMS-right ventricle mid peak systolic velocity, SSM-strain mid-septal }\end{array}$} \\
\hline
\end{tabular}

this activation such as natriuretic peptides may provide information about differential diagnosis and prognosis of heart failure. There is accumulating evidence regarding the presence of correlation between $B N P$ levels and $E F$, which reflects the degree of systolic functional impairment in heart failure (17). In the present 
study, a significant negative correlation between ejection fraction and BNP levels were demonstrated, which is in agreement with the results of previous studies. We also found that the ejection fraction values of patients with BNP levels above the median value were significantly lower than that of patients with BNP levels below the median value. Mayer et al. (18) detected a significant relation between BNP levels and LV end-diastolic diameter, LV end-systolic diameter, left atrial diameter and mitral regurgitation (MR) in a study conducted on patients with functional mitral regurgitation and heart failure. We also revealed significant relations between BNP levels and LV end-diastolic and end-systolic diameters and mitral regurgitation, whereas there was no statistically significant relation between BNP and left atrial diameter. Disturbances of diastolic function emerge, not only as one of the reasons of heart failure, but also as the first sign of cardiac involvement in various diseases, even when the patient is asymptomatic and has normal systolic functions $(19,20)$. The individual correlation of $A$ and $E$ peak velocity values with BNP levels did not exhibit a significant correlation in our study. However, there was a significant positive correlation between plasma BNP levels and E/A ratio, which has been suggested to provide a better reflection of LV diastolic function $(14,21)$.

Tissue Doppler parameters seem to be more sensitive in determining the subtle cardiac functional alterations than the conventional echocardiographic parameters $(13,22)$. The negative correlations between RV peak systolic pulsed-wave tissue Doppler velocities and BNP levels in our study may indicate that BNP levels may also increase in case of RV systolic dysfunction, just as in LV dysfunction $(23,24)$. As such, degree of pulmonary hypertension and its impact on right ventricle may decrease the specificity of plasma BNP levels for differential diagnosis of LV dysfunction.

Strain and strain rate analysis have been suggested to provide a reliable quantitative information for evaluation of the regional wall motion abnormalities $(25,26)$. When contractility of the myocardium is decreased regionally, the peak systolic strain value of this region decreases. Myocardial deformation is a complex parameter affected by the intrinsic contractility force of the myocardium, extrinsic filling status and the elastic properties of the tissue. Strain and strain rate parameters are not affected from rotational movements of the heart and the movements of neighboring segments in contrast to other parameters derived from tissue Doppler analysis. There are a limited number of studies comparing the BNP levels to strain and strain rate. When the strain and strain rates are individually correlated to BNP levels in our study, only peak systolic strain value from the middle portion of the septum was found to be significantly negatively correlated with BNP levels, which may be due to heterogeneity of study population regarding degree of systolic functional impairment of left and right ventricles.

\section{Study limitations}

This study was performed on a relatively small number of patients. There was significant heterogeneity regarding echocardiographic parameters reflecting the amount of deterioration of LV systolic and diastolic functions, which precluded multi- variate analysis for prediction of independent contribution of individual parameters to elevation of plasma BNP levels.

\section{Conclusion}

In summary, significant correlations between plasma BNP levels and various echocardiographic parameters reflecting left and right ventricular functions were demonstrated in our study. It seems that the degree of pulmonary hypertension and degree of right ventricular deterioration as a consequence of pulmonary hypertension and altered hemodynamics of left ventricle contributes to the rise of plasma BNP levels of heart failure patients presenting to emergency service with dyspnea.

Based on the results of this study, it might be logical to investigate plasma BNP levels in chronic obstructive pulmonary disease patients without LV dysfunction by additional studies. Such an evaluation may highlight the specificity of plasma BNP levels for differential diagnosis of heart failure in patients presenting to emergency service with acute dyspnea.

\section{Conflict of interests: None declared}

\section{References}

1. Muller C, Kuster G, Buttner HJ, Buser P. B-type natriuretic peptidecurrent use in the diagnosis and management of heart failure. Herz 2003; 28: 374-9.

2. Scardovi $A B$. Clinical applications of brain natriuretic peptide testing. Ital Heart J Suppl 2004; 5: 343-56.

3. McCullough PA, Sandberg KR. Sorting out the evidence on natriuretic peptides. Rev Cardiovasc Med 2003; 4: 13-9.

4. Cowie MR, Mendez GF. Brain natriuretic peptide and congestive heart failure. Prog Cardiovasc Dis 2002; 44: 293-21.

5. Meune C, Fulla Y, Martins E, Bergmann JF, Devaux JY. B-type natriuretic peptide for the diagnostic and prognostic assessment in cardiology. Its interest and perspectives of application. Presse Med 2003; 32: 181-5.

6. ACC/AHA Task Force. Guidelines for the evaluation and management of heart failure. Report of the American College of Cardiology/American Heart Association Task Force on Practice Guidelines (Committee on Evaluation and Management of Heart Failure). J Am Coll Cardiol 1995; 26: 1376-98.

7. Vasan RS, Benjamin EJ, Levy D. Prevalence, clinical features and prognosis of diastolic heart failure: an epidemiologic perspective. J Am Coll Cardiol 1995; 26: 1565-77.

8. Yamaguchi H, Yoshida J, Yamamoto K, Sakata Y, Mano T, Akehi N, et al. Elevation of brain natriuretic peptide is a hallmark of diastolic heart failure independent of ventricular hypertrophy. J Am Coll Cardiol 2004; 43: 55-60.

9. Troughton RW, Prior DL, Pereira JJ, Martin M, Fogarty A, Morehead A, et al. Plasma B-type natriuretic peptide levels in systolic heart failure: importance of left ventricular diastolic function and right ventricular systolic function. J Am Coll Cardiol 2004; 43: 416-22.

10. Weber M, Hamm C. Role of B-type natriuretic peptide and NT-proBNP in clinical routine. Heart 2006; 92: 843-9.

11. Ordonez-Lianos J, Merce-Muntanola J, Santalo-Bel M. Natriuretic peptide testing in emergency settings. Clin Chem Lab Med 2008; 46: 1543-9.

12. McKee PA, Castelli WP, McNamara PM, Kannel WB. The natural history of congestive heart failure: the Framingham study. N Engl J Med 1971; 285: 1441-6. 
13. Kepez A, Akdoğan A, Sade LE, Deniz A, Kalyoncu U, Karadağ 0, et al. Detection of subclinical cardiac involvement in systemic sclerosis by echocardiographic strain imaging. Echocardiography 2008; 25: 191-7.

14. Feigenbaum $H$, Armstrong WF, Ryan T. Evaluation of systolic and diastolic function of the left ventricle. In: Feigenbaum $\mathrm{H}$, Armstrong WF, Ryan T, editors. Feigenbaum's Echocardiography. $6^{\text {th }}$ ed. Philadelphia: Lippincott Williams \& Wilkins; 2005. p.138-81.

15. Harrison A, Morrisson LK, Krishnaswamy P. B-type natriuretic peptide predicts future cardiac events in patients presenting to the emergency department with dyspnea. Ann Emerg Med 2002; 39: 131-8.

16. Marantz PR, Kaplan MC, Alderman MH. Clinical diagnosis of congestive heart failure in patients with acute dyspnea. Chest 1990; 97: 776-81.

17. Kjaer A, Hildebrandt P, Appel J, Petersen CL. Neurohormones as markers of right- and left-sided cardiac dimensions and function in patients with untreated chronic heart failure. Int J Cardiol 2005; 99: 301-6.

18. Mayer SA, De Lemos JA, Murphy SA, Brooks S, Roberts BJ, Grayburn PA. Comparison of B-type natriuretic peptide levels in patients with heart failure with versus without mitral regurgitation. Am J Cardiol 2004; 93: 1002-6.

19. Poulsen SH. Clinical aspects of left ventricular diastolic function assessed by Doppler echocardiography following acute myocardial infarction. Dan Med. Bull 2001; 48: 199-10.
20. Vlahovic A, Popovic AD. Evaluation of left ventricular diastolic function using Doppler echocardiography. Med Pregl 1999; 52: 13-8.

21. Mandinov L, Eberli FR, Seiler C, Hess OM. Diastolic heart failure. Cardiovasc Res 2000; 45: 813-25.

22. Farias CA, Rodriguez L, Garcia MJ. Assessment of diastolic function by tissue Doppler echocardiography: comparison with standard transmitral and pulmonary venous flow. J Am Soc Echocardiogr 1999; 12: 609-17.

23. Passino C, Maria Sironi A, Favilli B, Poletti R, Prontera C, Ripoli A, et al. Right heart overload contributes to cardiac natriuretic hormone elevation in patients with heart failure. Int J Cardiol 2005; 104: 39-45.

24. Tulevski II, Groenink M, van Der Wall EE, van Veldhuisen DJ, Boomsma F, Stoker J, et al. Increased brain and atrial natriuretic peptides in patients with chronic right ventricular pressure overload: Correlation between plasma neurohormones and right ventricular dysfunction. Heart 2001; 86: 27-30.

25. Pelerin D, Sharma R, Elliott P. Tissue Doppler, strain, and strain rate echocardiography for the assessment of left and right systolic ventricular function. Heart 2003; 89: 9-17.

26. Kowalski M, Kukulski T, Jamal F, D'hooge J, Weidemann $F_{\text {, }}$ Rademakers $F$, et al. Can natural strain and strain rate quantify regional myocardial deformation? A study in healthy subjects. Ultrasound Med Biol 2001; 27: 1087-97. 